\title{
Test Study on Behavior of RC Beam to Concrete Filled Steel Tubular Column Joints
}

\author{
Qin Chen* and Lijun Liang \\ Hong Kong Hua Yi Design Consultants (S.Z.) LTD., Shenzhen 518057, China \\ *Corresponding author
}

\begin{abstract}
Two new type of RC beam to concrete filled steel tubular column joints are proposed here. Test study on 22 joint specimens under vertical load is introduced here, which includes RC beam to concrete filled steel tubular column joints with four types of connections and RC beam to circular column joints. The four types of connections are: connection without openings on steel tube, connection with openings and strengthened with RC ring beam, connection with openings and strengthened with three circumferential stiffening plates, and connection with openings and strengthened with five circumferential stiffening plates. Test results show that there are no obvious distinctions for the ultimate deformation capacities between the specimens with openings and specimens without openings. So all the connections with openings have enough energy dissipation capacity and these joints meet the requirements of design concept of strong connection.
\end{abstract}

Keywords-RC beam to concrete filled steel tubular column joints; RC beam to circular column joints; test study; openings on steel tube; circumferential stiffening plates

\section{INTRODUCTION}

Concrete filled steel tubular (CFST) columns have high bearing capacity, excellent ductility and earthquake-resistant performances, and have been widely used as vertical components in high-rise buildings. By considering economic factors and fireproofing requirements, reinforced concrete beams are usually used together with concrete filled steel tubular columns to form frame structures. Due to the existence of steel tube, longitudinal reinforcement of RC beam cannot be anchored in the joint core conveniently; inner forces of beam end cannot be transferred to column efficiently. Therefore the design on RC beam to CFST column joints has become a key point and difficult problem, which has been a substantial influence on the application of the kind of column. Some approaches for the joint design were recommended in Chinese design code[1], and some new types of joints were developed recently[2-4]. Measures as setting steel corbel, ring beam or small openings on steel tube for reinforcement bars are applied in these recommended joints, which have complicated structures and cause difficult design and construction. Two new type of RC beam to concrete filled steel tubular column joints are proposed here, by setting large openings and corresponding strengthening measures, the longitudinal reinforcement bars of beams can be anchored in the joint core, then the inner force transferring in the joints is easy to realize. Test study on the new joints under static load is presented in this paper, and the test results proved that the new joints have excellent bearing capacity and deformability.

\section{DESCRIPTION OF THE TEST}

The new RC beam to concrete filled steel tubular column joints proposed here include two types: in the first type, reinforced concrete ring beam are set outside of the steel tube and with large openings on the steel tube; in the second type, circumferential stiffening steel plates and vertical stiffening steel plates are set around the large openings on steel tube. In the first type of joint specimen, one circumferential stiffening steel plate is weld on the top of the ring beam outside of the steel tube. In the second type of joint specimen, there are three or five circumferential stiffening steel plates along the beam height. As the comparison specimens, precast RC beam to concrete filled steel tubular column joints without openings on steel tube are produced, the longitudinal reinforcement bars are welded on the pre-embedded plates in the beam, and the plates are welded with the steel corbels set on the steel tubes. In order to study the mechanics behaviors between concrete filled steel tubular column and RC circular columns, RC beam to circular column joint specimens are tested too.

22 joint specimens are made in the test, and there are four RC beams orthogonal to each other in each specimen. All the specimens have the same overall dimension, the specimen height is $1000 \mathrm{~mm}$. The diameter of columns is $300 \mathrm{~mm}$, beam area is $80 \mathrm{mmX} 140 \mathrm{~mm}$, and wall-thickness is $3.2 \mathrm{~mm}$. The specimens set with RC ring beam and with large openings on the steel tubes are named as SJ1, the specimens strengthened with three circumferential stiffening steel plates and with large openings on the steel tubes are named as SJ2, the specimens strengthened with five circumferential stiffening steel plates and with large openings on the steel tubes are named as SJ3, the precast RC beam to concrete filled steel tubular column joint specimens are named as SJ4, and RC beam to circular column joint specimens are named as J5. The elevations of five type of specimens are shown as Figure 1. The number of all specimens is list as Table 1.

Test loading device is shown as Figure 2, which includes 1000 ton fluid pressure operated jacks. The stain of steel tube, reinforcement and concrete are collected by strain gages, and the vertical deformation of columns are collected by displacement sensors. The vertical pressure is recorded by pressure sensors, whose time interval are 1 second. The strength of steel and concrete were measured before the tests, the steel strength is $248 \mathrm{MPa}$ to $289 \mathrm{MPa}$, and the concrete 
strength is 30MPa. The loading test scheme is set as multistage loading, each stage of load is stable about 2 minutes before the next loading until the specimen is broken. The photo of test loading is shown as Figure 3.

TABLE I. TABLE TYPE STYLES

\begin{tabular}{|c|c|}
\hline Specimen Type & Table Column Head \\
\hline SJ1 & $2,4,5,6$ \\
\hline SJ2 & $8,12,13,15$ \\
\hline SJ3 & $9,10,11,14,16$ \\
\hline SJ4 & $7,17,18,19,20$ \\
\hline J5 & $1,3,21,22$ \\
\hline
\end{tabular}

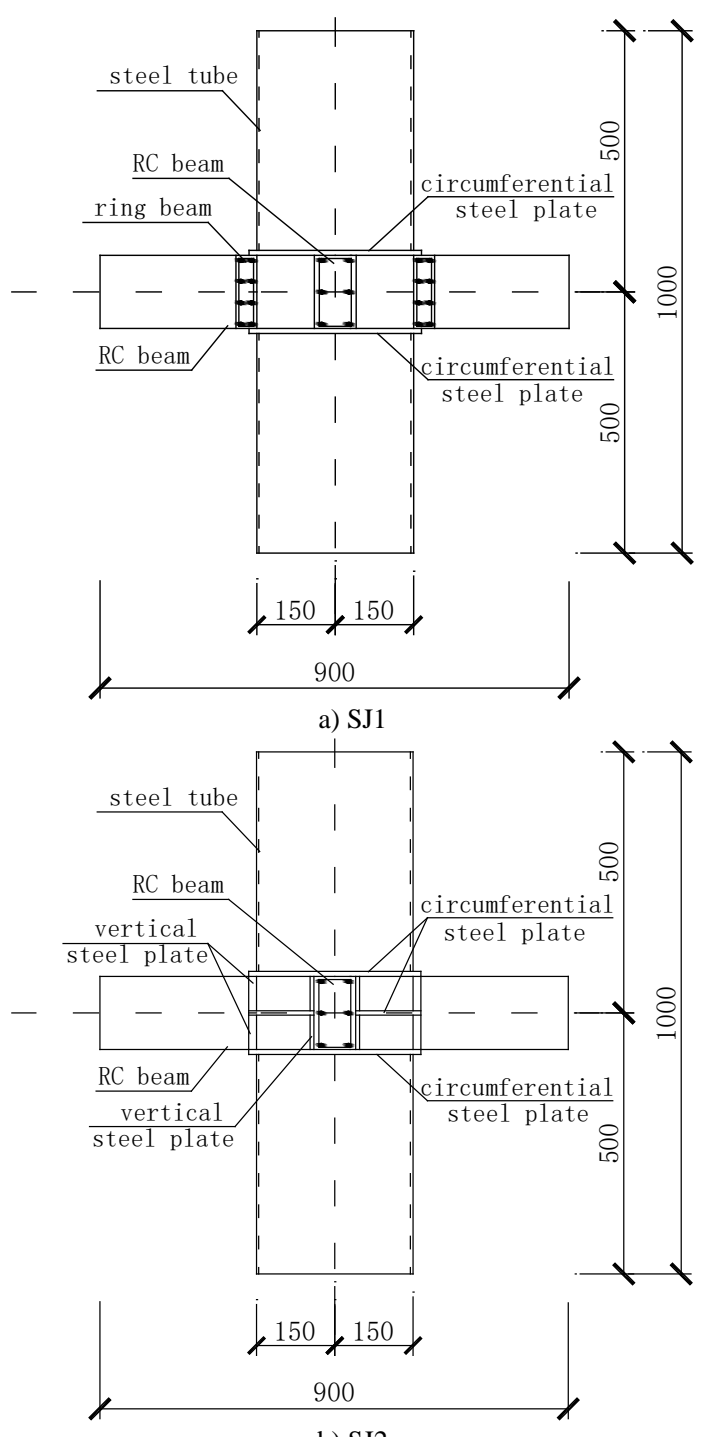

b) $\mathrm{SJ} 2$

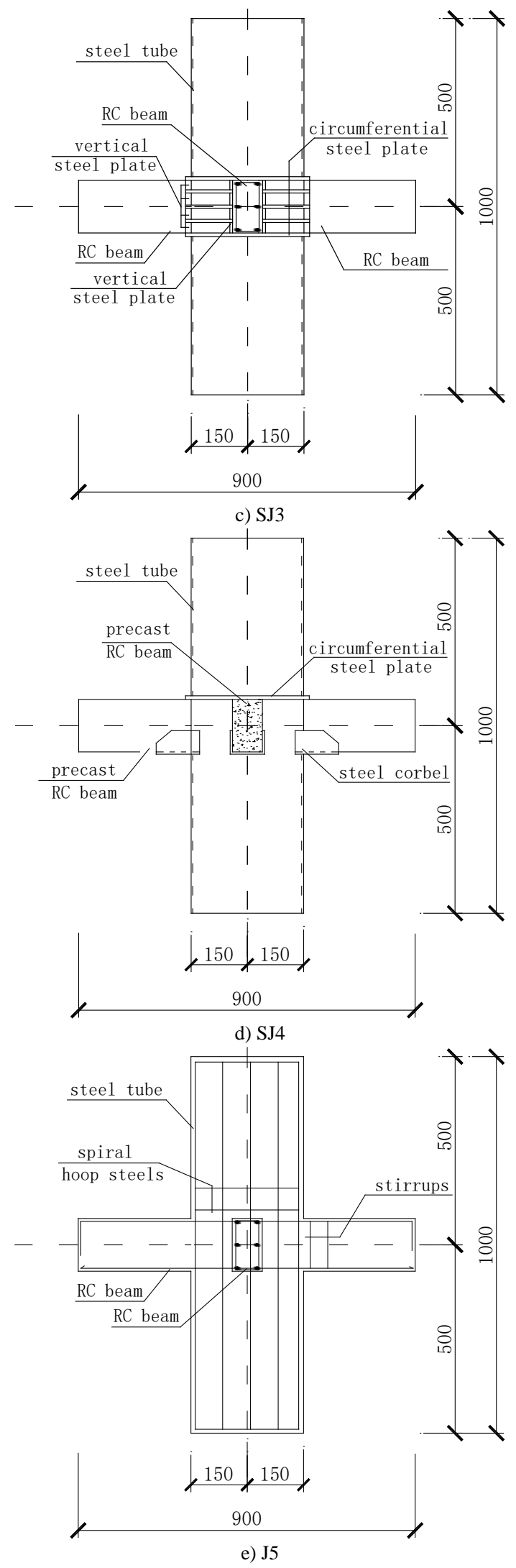

FIGURE I. THE ELEVATIONS OF SPECIMENS 
Test loading device is shown as Figure 2, which includes 1000 ton fluid pressure operated jacks. The stain of steel tube, reinforcement and concrete are collected by strain gages, and the vertical deformation of columns are collected by displacement sensors. The vertical pressure is recorded by pressure sensors, whose time interval are 1 second. The strength of steel and concrete were measured before the tests, the steel strength is $248 \mathrm{MPa}$ to $289 \mathrm{MPa}$, and the concrete strength is $30 \mathrm{MPa}$. The loading test scheme is set as multistage loading, each stage of load is stable about 2 minutes before the next loading until the specimen is broken. The photo of test loading is shown as Figure 3.

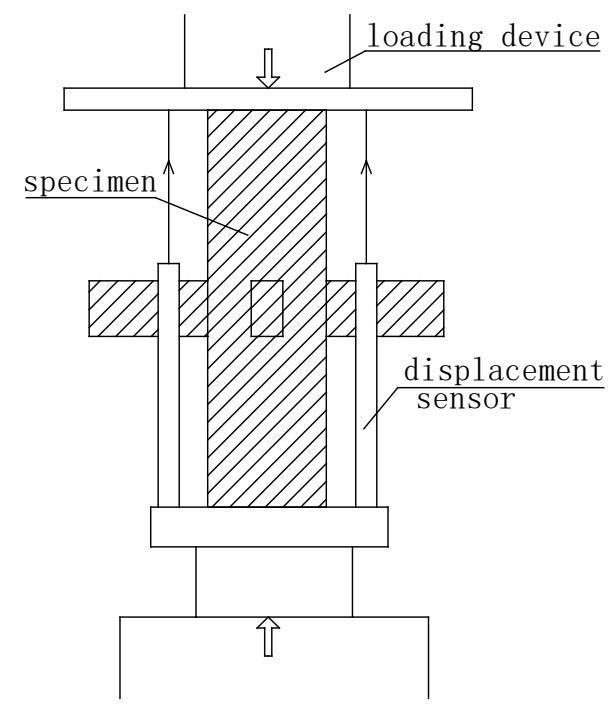

FIGURE II. TEST LOADING DEVICE

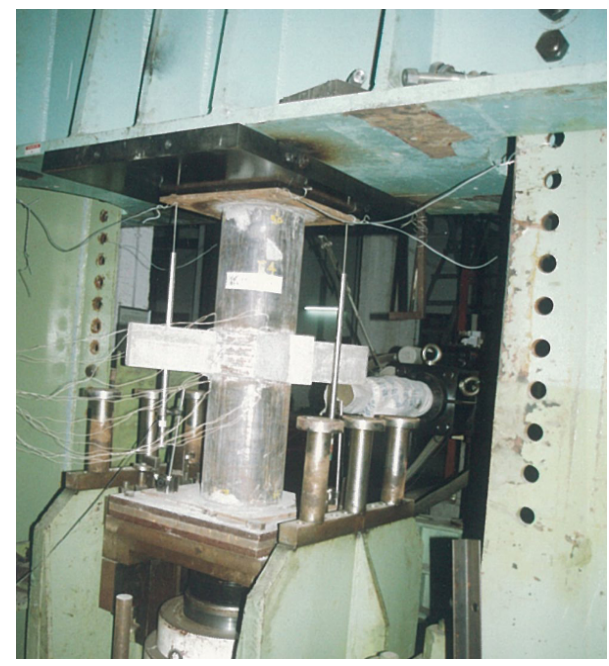

FIGURE III. TEST PHOTO

\section{TeSt RESULTS AND ANALYSIS}

\section{A. Failure Mode of Specimens}

Typical failure mod of all the type of the specimens are shown as Figure 4. For the four type of RC beam to concrete filled steel tubular column joints, the failure are focus above or under the intersections between beam and column, steel tube

bulge at the same placement, and less concrete crush is observed at the RC ring beam in specimens SJ1. Serious crush are occurred at the top and bottom concrete of RC beam to circular column joint specimens J5, steel ring hoops are exposed. The results reveal that the RC beam to circular column joint specimens suffered more severe damage than RC beam to concrete filled steel tubular column joint specimens.

\section{B. Strain and Deformations}

The relationship diagram of circumferencial strain of steel tube or steel ring hoop to vertical load of all type of specimens is shown as Figure 5. The result show that the circumferencial stress of steel tube do not yield, and the steel tubes are still in elastic situation till the concrete filled steel tubular columns suffer the ultimate loading. The cracking of welding seam does not occur during the whole tests. The deformation capacity diagrams of specimens are shown as Figure 6.

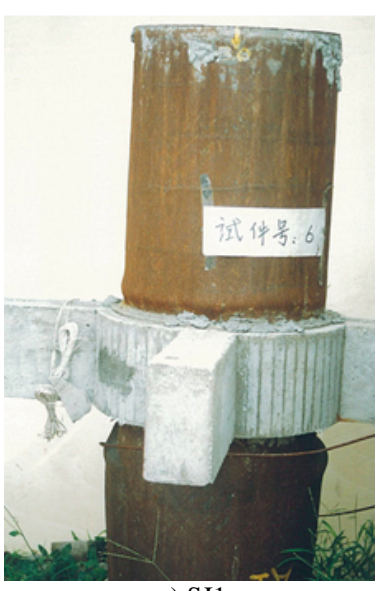

a) $\mathrm{SJ} 1$
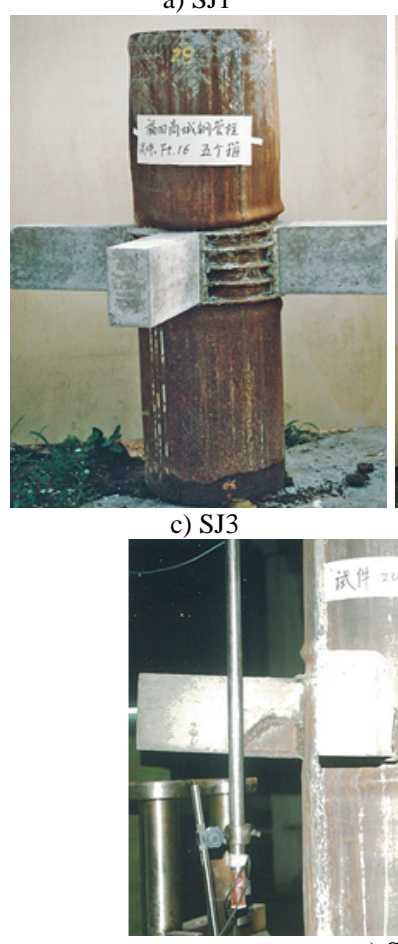

FIGURE IV

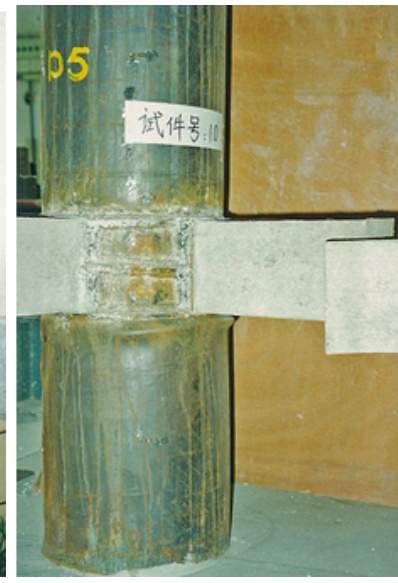

b) $\mathrm{SJ} 2$

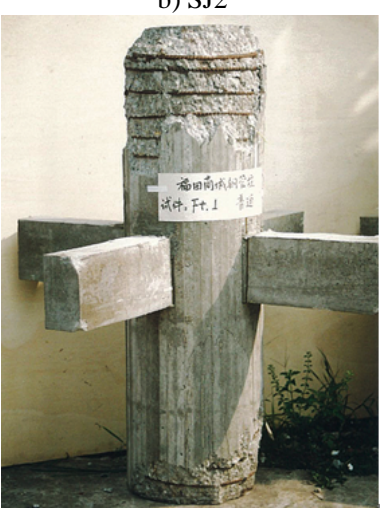

d) J5

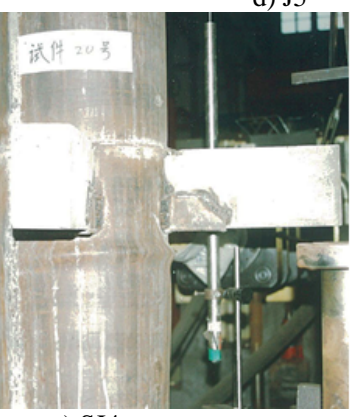

e) $\mathrm{SJ} 4$

FAILURE OF SPECIMENS 


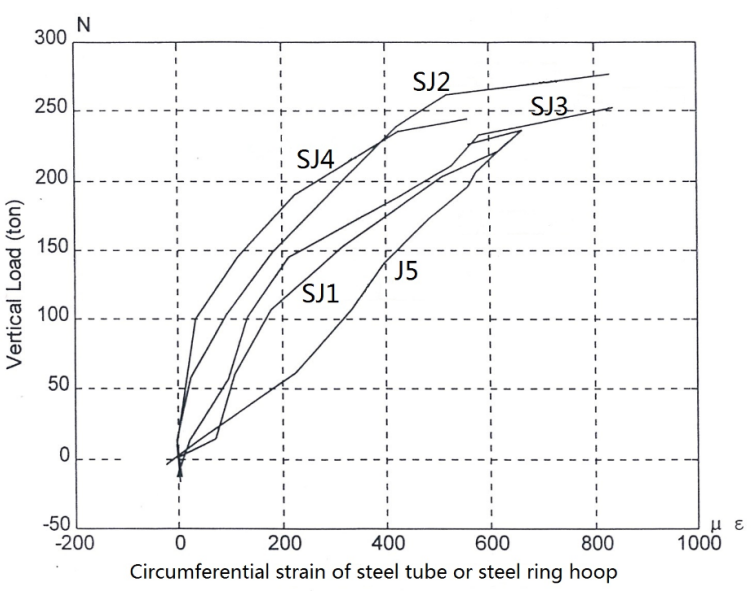

FIGURE V. CIRCUMFERENTIAL STRAIN AND VERTICAL LOAD DIAGRAMS

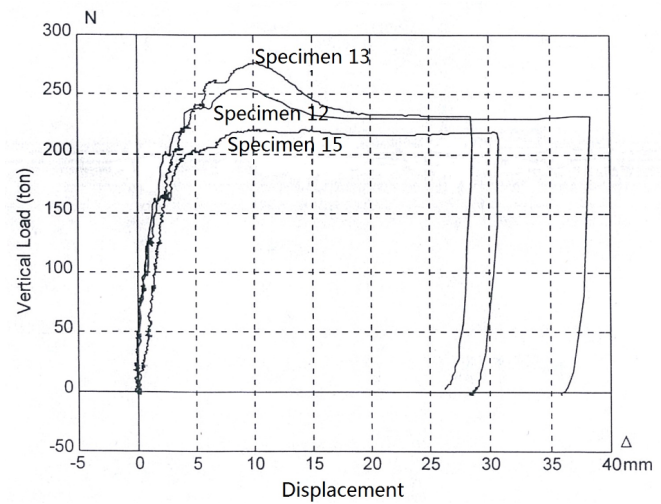

a) $\mathrm{SJ} 2$

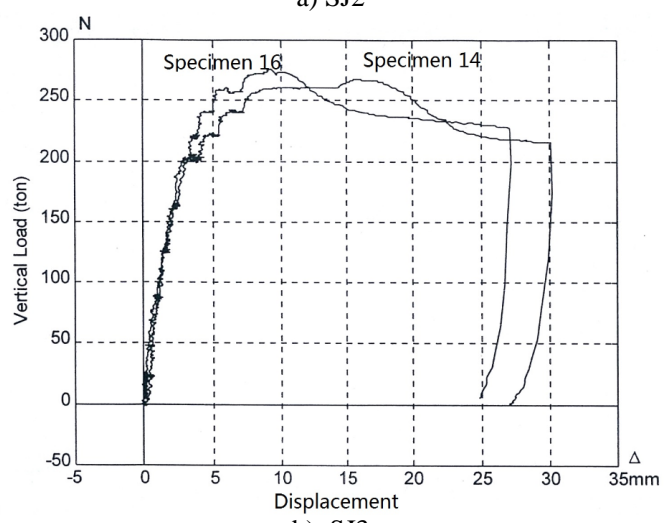

b) $\mathrm{SJ} 3$

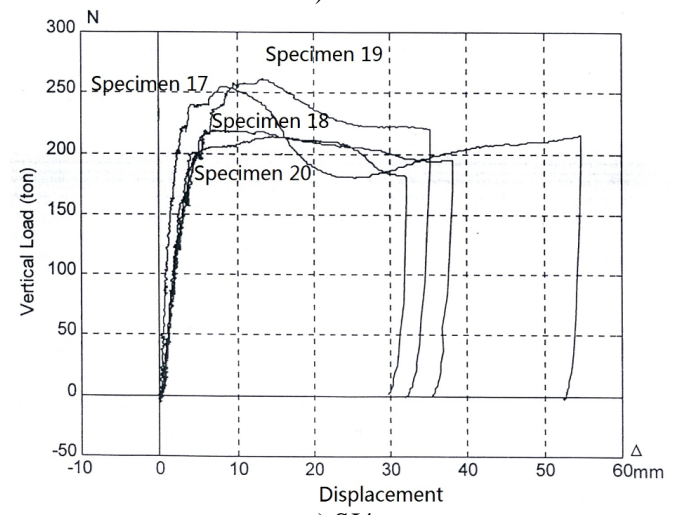

c) $\mathrm{SJ} 4$

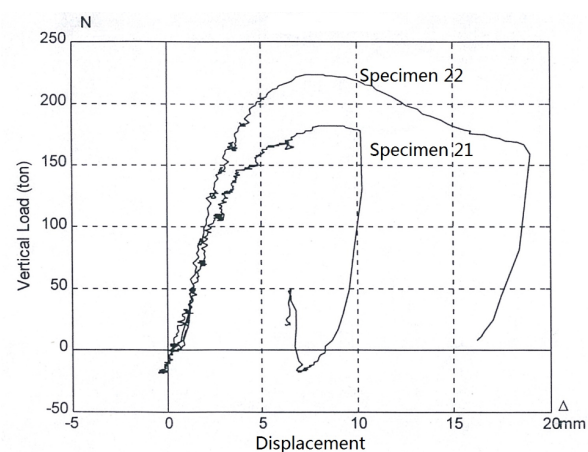

d) J5

FIGURE VI. DEFORMATION CAPACITY DIAGRAMS

From the test study the following conclusions can be drawn:

1. There are no significant differences between specimens SJ2 and SJ3, which are strengthened with three or five circumferential stiffening plates for large openings, with respect to ultimate bearing capacity and deformation capacity. Therefore, the joint with large openings strengthened with three circumferential stiffening plates can satisfy with the application demand.

2. The ultimate bearing capacity of joints with large openings by using strengthening measures does not decrease obviously, compared with the joints without large openings.

3. There similar ultimate deformation capacity for all the concrete filled steel tubular column joints, and their capacity is $250 \%$ higher than that of RC circular column joints.

4. As for concrete filled steel tubular column joints with large openings, the stiffness of the joint core is increased by strengthening measure, the circumferential deformation of joint core is less than that of other parts.

\section{CONCLUSIONS}

Test study on the proposed new type of joints specimens shown that the ultimate strength and deformation capacity for the three types of connections with openings on steel tube do not decrease compared with that of the connection without openings on steel tube. The proposed RC beam to concrete filled steel tubular column joints with openings have enough energy dissipation capacity and their structures are simpler than the previous joints, therefore they can be widely applied in seismic design for high-rise building.

\section{REFERENCES}

[1] Technical specification for concrete-filled steel tubular structures. CECS 28:2012. 2012. China Planning Press, Beijing.

[2] J. Zhang, C. Liu, C.J. Tan and B.Y. Li, "Design and finite element analysis of a new concrete-filled steel tubular column and reinforced concrete beam joint,” Building Structure. Beijing, vol 41(S1), pp. 4852, April 2011.

[3] G.H. Yao, Y.Y. Chen, Y.J. Huang and D.H. Pan, "Experimental study on seismic behavior of joint of CFST column-RC beam,” Industrial Construction. Beijing, vol 41(2), pp. 97-101, May 2011.

[4] H. Qu, L.H. Han and Z. Tao, "Seismic performance of reinforced concrete beam to concrete-filled steel tubular columns joints," Key Engineering Materials. Beijing, vol 35, pp. 685-691, Dec 2009. 